\title{
ROLA CZYNNIKA LUDZKIEGO W UNOWOCZEŚNIANIU POLSKIEGO ROLNICTWA NA PRZYKLADZIE PRODUCENTÓW MLEKA ${ }^{1}$
}

\begin{abstract}
Zarys treści: Postęp wdrażany w produkcji rolnej uwarunkowany jest wieloma czynnikami, wśród których dużą wagę przypisuje się postawie producentów rolnych. $Z$ tego względu główny cel opracowania skoncentrowano na samoocenie kompetencji posiadanych przez producentów rolnych niezbędnych w procesie unowocześniania ich gospodarstw. Zwrócono także uwagę na wykształcenie rolników, źródła pozyskiwania wiedzy oraz sposoby jej uaktualniania. Podstawowym źródłem informacji były dane pierwotne zgromadzone metodą wywiadu bezpośredniego przeprowadzonego z właścicielami 74 gospodarstw mleczarskich z województwa warmińsko-mazurskiego. Do analizy pozyskanego materiału badawczego wykorzystano statystyki opisowe oraz wskaźnik ważności. $\mathrm{Na}$ podstawie przeprowadzonych badań nie stwierdzono związku pomiędzy realizowaniem lub nierealizowaniem inwestycji a wiekiem i wykształceniem. Dokonana pod względem ważności hierarchizacja kompetencji pozwoliła stwierdzić, że w procesie unowocześniania badanych gospodarstw mleczarskich najważniejsze były chęć do nauki i zorientowanie na wiedzę.
\end{abstract}

Słowa kluczowe: kapitał ludzki, innowacje, produkcja mleka, unowocześnianie.

\section{Wstęp}

Rolnictwo jest sektorem gospodarki, który realizuje funkcje związane z produkcją żywności, decydując tym samym o bezpieczeństwie żywnościowym kraju. Jego relatywna pozycja w gospodarce narodowej, mierzona za pomocą tradycyjnych wskaźników, zmniejsza się, głównie ze względu na niższą dochodową elastyczność popytu na produkty żywnościowe niż na inne dobra i usługi, wyższe tempo wzrostu wydajności czynników produkcji w rolnictwie w porównaniu do tempa wzrostu popytu oraz ograniczone zapotrzebowanie na produkty

\footnotetext{
${ }^{1}$ Projekt został sfinansowany ze środków Narodowego Centrum Nauki przyznanych na podstawie decyzji numer DEC-2011/03/D/HS4/04248.
} 
żywnościowe. Jednak związki rolnictwa z całą gospodarką zacieśniają się m.in. ze względu na fakt, że rolnictwo przestaje być autonomicznym ogniwem w procesie produkcji żywności, a staje się częścią spójnego systemu agrobiznesu (Kowalski 2009, 2010).

Rolnictwo w XXI wieku musi zmierzyć się z takimi wyzwaniami jak: zrównoważony rozwój czy ochrona środowiska vs. poprawa efektywności (Jain 2012), w tle których jawi się stale rosnący globalny popyt na żywność. Postępy, jakich dokonano przez dziesięciolecia $\mathrm{w}$ rolnictwie pozwoliły pogodzić produkcję z koniecznością zrównoważonego gospodarowania zasobami naturalnymi oraz ochroną środowiska naturalnego. Istnieje jednak obawa, że oczekiwania wzrostu produkcji rolnej w związku z rosnącym popytem na żywność spowodują dalszą degradację zasobów naturalnych i środowiska. $Z$ tego powodu ważne jest wdrażanie innowacyjnych rozwiązań, które z jednej strony pozwolą zwiększyć produkcję, z drugiej - zapobiegać będą degradacji zdolności produkcyjnych, głównie zasobów naturalnych, a więc gleby, wody i ekosystemów (Glejbowicz, Chlebicka 2012).

Pojęcie innowacji jest stosunkowo rzadko stosowane w odniesieniu do rolnictwa. Dużo częściej używa się określenia „postęp naukowo-techniczny”. Ów postęp odnosi się do cyklu zmian spowodowanych bodźcami posiadającymi cechy nowości, celowo wprowadzanymi przez człowieka, powtarzalnymi w dowolnym czasie i przestrzeni, wywołującymi pozytywnie oceniane efekty. Postęp w rolnictwie oznacza wszystko, co jest wprowadzane do produkcji i życia społecznego wsi, jako nowe w określonym miejscu i czasie w celu uzyskania lepszych efektów produkcyjnych, ekonomicznych, jak również podniesienia poziomu kultury i dobrobytu (Krzyżanowska 2000). Najczęściej postępowe zmiany w produkcji roślinnej, zwierzęcej czy wyposażeniu technicznym są wynikiem zastosowania innowacji rozumianych jako materialne odpowiedniki myśli czy idei. Trzeba mieć jednak świadomość, że możliwe jest także wprowadzenie w gospodarstwach rolnych innowacji o charakterze organizacyjnym, sprowadzających się np. do wdrożenia nowych koncepcji organizacji procesu produkcji. W opracowaniu przyjęto za: A. Wosiem (1987), że pod pojęciem innowacji na poziomie gospodarstwa można rozumieć dotychczas niestosowane nowe:

- wytwory, a zatem: środki, narzędzia pracy i techniczne środki produkcji, materiały nasienne i hodowlane, środki chemiczne, urządzenia gospodarcze związane $\mathrm{z}$ budownictwem, transportem, przechowalnictwem, zaopatrzeniem i zbytem produktów rolnych,

- sposoby gospodarowania - proste i złożone operacje technologiczne w poszczególnych działaniach i gałęziach produkcji,

- koncepcje i metody kierowania gospodarstwem, które są związane z celami, kierunkami, strukturą i ekonomiką produkcji.

Możliwości rozwojowe rolnictwa są coraz częściej uwarunkowane egzogenicznie. Oznacza to, że nowe lub udoskonalone organizmy roślinne lub 
zwierzęce, urządzenia, środki produkcji oraz rozwiązania wykorzystywane $\mathrm{w}$ rolnictwie tworzone są poza nim - w innych sektorach (Babuchowska $\mathrm{i}$ in. 2013). W procesie wprowadzania innowacji w sektorze rolnym bardzo ważne jest także otoczenie instytucjonalne, obejmujące zbiór organizacji rządowych działających na rzecz rolnictwa wraz z kreowanymi przez nie instrumentami, jak również podmioty, które wpływają na realizację transakcji rolnictwa $\mathrm{z}$ otoczeniem (Staniszewski 2014). Instytucje otoczenia rolnictwa, np. ośrodki doradztwa rolniczego, uczestniczą $\mathrm{w}$ procesie wdrażania rezultatów badań naukowych do praktyki.

Podkreśla się, że rozwój innowacyjności rolnictwa jest hamowany przez wiele barier, z których większość ma charakter endogeniczny. Zasadniczą kwestią jest fakt, że rolnictwo wykorzystuje dostępne zasoby naturalne, a one są ograniczone. Ważna jest także postawa producentów rolnych przejawiająca się w skłonności do wprowadzania nowych rozwiązań. Współcześnie najbardziej dynamicznym czynnikiem wzrostu gospodarczego i konkurencyjności gospodarki jest kapitał ludzki. Dotyczy to zdolności nabywania i rozwijania unikatowych umiejętności, a także właściwego reagowania na zmiany (Kożuch, Kożuch 2008). Zgodnie z definicją OECD (1998) kapitał ludzki może być definiowany jako ucieleśnione $\mathrm{w}$ jednostce umiejętności, kompetencje, wiedza, które są istotne w działalności gospodarczej. W człowieku - jego umiejętnościach i podstawach - tkwi najważniejszy potencjał produkcyjny i źródło dobrobytu narodów (Gradziuk 2008, za: Wilkin 2006). Dążąc do zaspokojenia materialnych potrzeb, czy to indywidualnych, czy zbiorowych, człowiek przekształca pierwotne w swej postaci zasoby w nowe. Podstawowa działalność człowieka odnosi się do takiego kształtowania właściwości środowiska, by możliwie w pełen sposób zaspokoić zróżnicowane potrzeby ludzkie (Parysek 2001). Można zatem uznać, że czynnik ludzki jest najistotniejszym zasobem każdej organizacji, także gospodarstwa rolnego, decydując o jej przewadze nad konkurentami (Rosińska 2007).

Teoria kapitału ludzkiego stała się bardzo ważnym elementem wszechstronnej analizy roli jakości czynnika ludzkiego w procesach ekonomicznych (Jarecki 2003; Marks-Bielska 2006). Po przystąpieniu Polski do UE, wraz ze zwiększającą się konkurencją na rynku producentów rolnych, wzrosło znaczenie jakości kapitału ludzkiego w rolnictwie. Konieczność dokonania zmian w sferze społeczno-ekonomicznej znajduje swój wyraz w licznych działaniach mających na celu przyspieszenie wymiany pokoleniowej wśród rolników, czy też wsparcie działalności rolnej wśród osób młodych. Zakłada się bowiem, że przejmowanie gospodarstw rolnych przez osoby młode sprzyja zachowaniom proinwestycyjnym i przyczynia się do poprawy kondycji ekonomicznej gospodarstw (Dudek 2008).

Głównym celem opracowania była samoocena kompetencji posiadanych przez producentów rolnych niezbędnych $\mathrm{w}$ procesie unowocześniania ich gospodarstw. Zwrócono także uwagę na wykształcenie rolników, źródła pozy- 
skiwania wiedzy oraz sposoby jej uaktualniania. Ze względu na fakt, że po akcesji Polski do UE nastąpiła intensyfikacja zmian związanych $\mathrm{z}$ modernizacją ${ }^{2}$ i unowocześnianiem polskich gospodarstw rolnych, badaniami objęto okres po 2004 roku. W opracowaniu zaprezentowano także zakres zmian, przede wszystkim o charakterze inwestycyjnym, wprowadzanych $\mathrm{w}$ gospodarstwach rolnych.

Podstawowym zbiorem informacji były dane pierwotne zgromadzone metodą wywiadu bezpośredniego przeprowadzonego z właścicielami 74 gospodarstw rolnych z województwa warmińsko-mazurskiego ${ }^{3}$ Dobór jednostek do badań był nielosowy (dobór wygodny). Warunkiem uczestnictwa w badaniu określonego producenta rolnego było prowadzenie działalności rolniczej na terenie województwa warmińsko-mazurskiego. Ze względu na dużą różnorodność kierunków prowadzonej działalności rolniczej zdecydowano o skoncentrowaniu badań na jednym - produkcji mleka. Dobór taki podyktowany był również faktem, że wyniki wcześniejszych badań autorek wykazały, iż producenci mleka wykazują się wysoką skłonnością do wprowadzania innowacji (Babuchowska i in. 2013).

Aby uzyskać możliwie obszerny obraz zmian dokonywanych w gospodarstwach objętych badaniami, w wielu pytaniach możliwe było udzielenie więcej niż jednej odpowiedzi. Z kolei w pytaniu dotyczącym oceny własnych kompetencji ${ }^{4}$ respondenci operując ocenami od 1 do 5 , gdzie 1 oznaczało

\footnotetext{
${ }^{2}$ Modernizacja semantycznie oznacza przede wszystkim uwspółcześnienie, unowocześnienie poprzez zerwanie z tradycją, uczynienie czegoś mniej staroświeckim. Termin ten znaczeniowo jest bliski transformacji, ponieważ $\mathrm{w}$ obu przypadkach mamy do czynienia ze zmianami w korzystnym kierunku. W języku potocznym oraz $\mathrm{w}$ nauce dostrzec można jednak pewną różnicę - modernizacja częściej kojarzona jest z postępem (Babuchowska, Marks-Bielska 2012, za: Lubbe 2011). Modernizacja jest związana z procesem przemian, których celem jest poprawa warunków działalności we wszystkich sferach gospodarczych i społecznych. Kierunek tych zmian związany jest z procesami unowocześniania technicznego, technologicznego oraz organizacyjnego m.in. przez wzrost sprawności, trwałości i niezawodności czynników wytwórczych, a także poprawę warunków ergonomicznych (Chyłek 2005).

${ }^{3}$ Odnosząc liczebność badanej grupy do liczby wszystkich producentów mleka w województwie, badani stanowili około $1 \%$ populacji. Liczebność próby nie daje zatem podstaw o uogólnienia wniosków na całą populację, ale stanowi ważny przyczynek do kontynuacji podjętych badań.

${ }^{4}$ Kompetencje są różnie definiowane. Często utożsamiane są jako wiedza, umiejętności, doświadczenie, charakteryzujące daną organizację. Kompetencje mogą być kluczowym czynnikiem sukcesu danego podmiotu. Pojęcie kompetencji jest także związane z właściwościami osobowymi pojedynczych osób, które są konieczne do odpowiedniego wykonania pracy na określonym stanowisku. Niektóre zadania wymagają posiadania kilku kompetencji (Dudzińska-Głaz 2012). W badaniach na podstawie literatury przedmiotu wyodrębniono 19 kompetencji, którymi powinien charakteryzować się ukierunkowany na rozwój gospodarstwa producent rolny.
} 
poziom bardzo niski, 2 - niski, 3 - przeciętny, 4 - wysoki, 5 - bardzo wysoki, mogli nadać odpowiedzi odpowiednią ważność.

W celu interpretacji zgromadzonych informacji wykorzystano takie miary jak: średnia arytmetyczna, mediana, odchylenie standardowe, współczynnik dyspersji oraz wskaźnik ważności zastosowany przez M. Kolę, M. Kujawkę i M. Kuzela (2005). Wskaźnik ten obliczono według następującej formuły:

$$
W=\frac{\sum_{i=1}^{k} n_{i} w_{i}}{k N}
$$

gdzie:

$W$ - wskaźnik ważności

$i$ - indeks oceny

$n i$ - liczba wskazań danego czynnika na i-tym miejscu

$k$ - maksymalna ocena w skali od 1 do $\mathrm{k}$

$N$ - liczba respondentów, którzy odpowiedzieli na pytanie

$w i$ - ocena odpowiadająca miejscu czynnika i (wskaźnik przyjmuje wartości od 0 do 1 , im jego wartość jest wyższa tym badana kompetencja jest ważniej-sza).

Obliczenie wskaźnika ważności miało na celu ukazanie danej kompetencji w hierarchii ważności.

\section{Wyniki badań empirycznych}

Po akcesji Polski do UE tempo zmian w polskim rolnictwie uległo przyspieszeniu. W pierwszych latach członkostwa dominowały czynniki sprzyjające wzrostowi produkcji i dochodów rolniczych. Sytuacja ta była rezultatem uczestnictwa Polski w Jednolitym Rynku Europejskim, które spowodowało wzrost popytu na polskie produkty rolne i żywnościowe. Towarzyszył temu realny wzrost cen tej grupy produktów. Korzystnie na sytuację w rolnictwie wpłynęły także subwencje otrzymane ze środków kierowanych na wspólną politykę rolną UE. Przełożyło się to na stopę inwestycji w rolnictwie, która od 2004 do 2008 roku systematycznie rosła (Kisiel, Babuchowska 2013).

W świetle wyników badań własnych stwierdzono, że w 68 spośród 74 objętych badaniem gospodarstw mleczarskich w latach 2004-2013 zrealizowano inwestycje. Najczęściej były one związane z zakupem maszyn i urządzeń $(92,6 \%$ wska-zań) oraz modernizacją lub rozbudową pomieszczeń gospodarczych $(69,1 \%$ wskazań). Co ważne, w wielu przypadkach wdrażane rozwiązania lub nabyte przez producentów rolnych urządzenia miały charakter rozwiązań dotychczas niestosowanych w gospodarstwie. Nosiły zatem cechy nowości. W przypadku prawie 59\% respondentów były to nowe narzędzia prac lub inne techniczne środki produkcji. Część respondentów zdecydowała się także na inwestycje w dotychczas nie stosowany materiał nasienny lub hodowlany $(4,41 \%)$, czy też wdrożenie nowych sposobów gospodarowania $(8,82 \%)$ (rys. 1). 


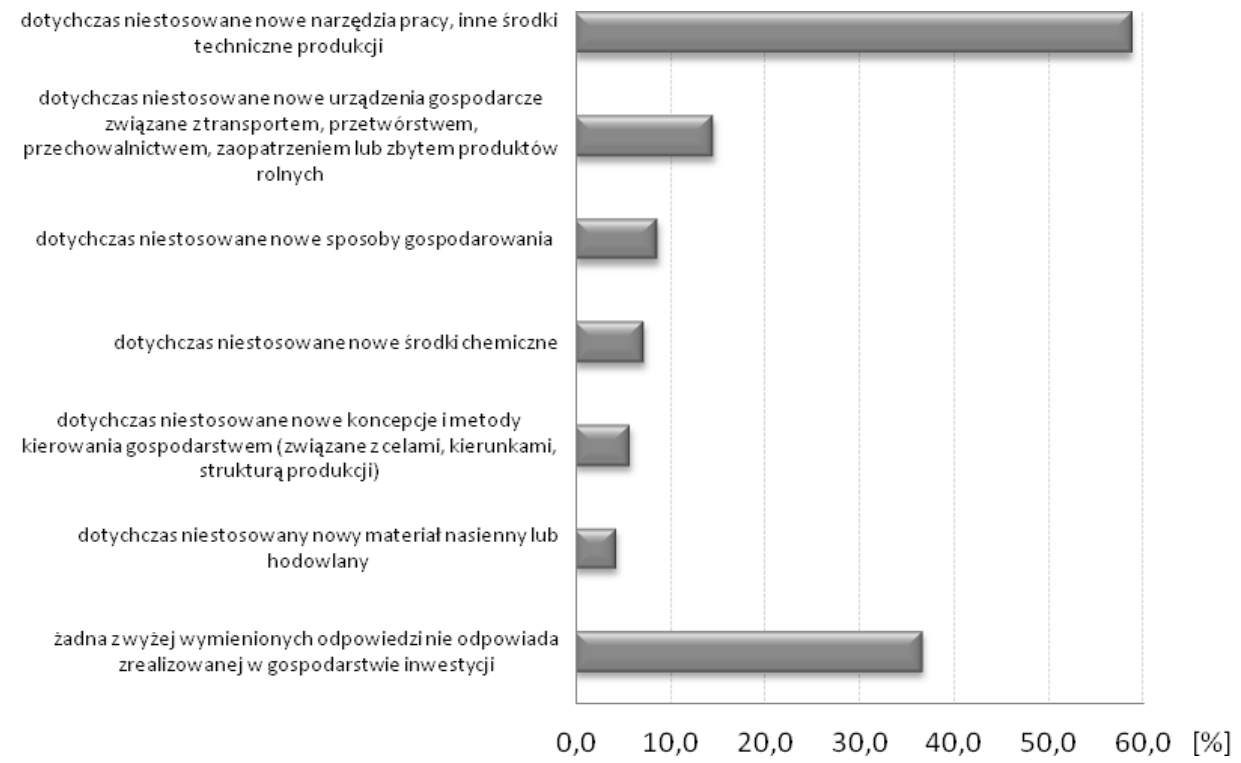

Rys. 1. Zakres inwestycji zrealizowanych w latach 2004-2013

Źródło: opracowanie na podstawie wyników badań własnych, $\mathrm{n}=68$

W większości zrealizowane inwestycje były innowacją wyłącznie w skali gospodarstwa $(67,65 \%)$. Jednak w badanej grupie znaleźli się i tacy producenci rolni, którzy podkreślali, że wdrożone zmiany były nowością w skali gminy $(13,24 \%)$, regionu $(4,41 \%)$, a nawet kraju (1,47\%) (rys. 2).

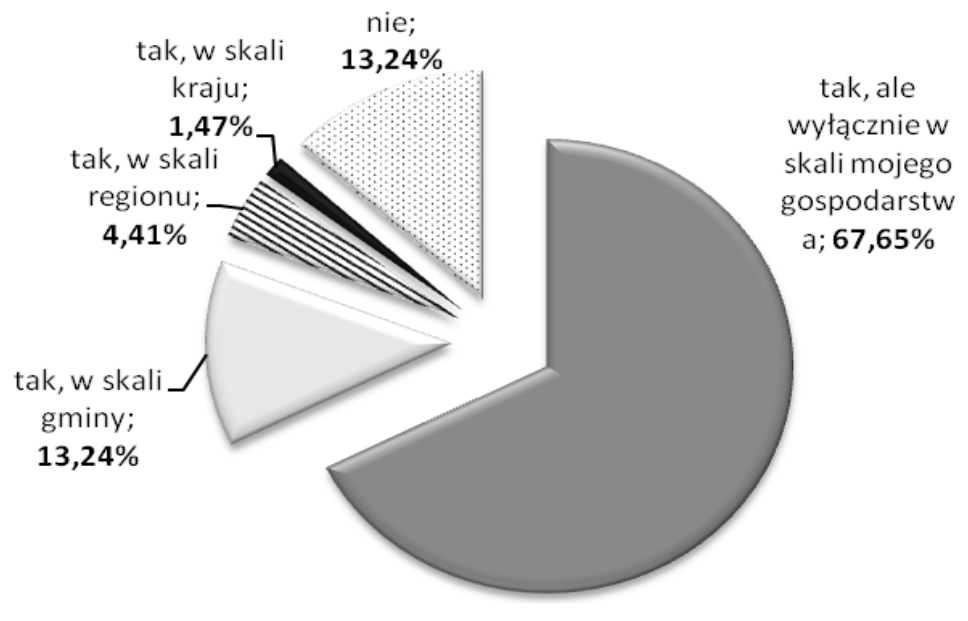

Rys. 2. Czy wprowadzone inwestycje miały charakter nowości

Źródło: opracowanie na podstawie wyników badań własnych, $\mathrm{n}=68$ 
Analizując proces zmian na obszarach wiejskich w naszym kraju, a także w funkcjonowaniu polskich gospodarstw rolnych nie sposób więc pominąć kwestii kapitału ludzkiego i szczegółowej jego charakterystyki ${ }^{5}$.

Podejmując próbę pomiaru kapitału ludzkiego zwykle bierze się pod uwagę cechy społeczno-demograficzne, jak: poziom wykształcenia, wiek, stan zdrowia, umiejętności. Semantycznie, mimo że kapitał ludzki tworzą cechy pojedynczych osób, jest on rozpatrywany w odniesieniu do ogółu (Dudek, Chmieliński 2011). W badanej grupie ponad połowa osób była w wieku 41-55 lat, 20 respondentów miało od 25 do 40 lat, a $11-56-65$ lat. Tylko 4 rolników było bardzo młodych i nie skończyli jeszcze 25. roku życia. Uczestniczący w badaniu producenci rolni byli mocno zróżnicowani pod względem wykształcenia. Wykształcenie kierunkowe (rolnicze) posiadało ponad $60 \%$ badanych, w tej grupie było 16 osób $\mathrm{z}$ wykształceniem zawodowym, $17-\mathrm{z}$ wykształceniem średnim i $15-\mathrm{z}$ wyższym. Dostrzeżono także stosunkowo wysoki udział (16,22\%) osób charakteryzujących się wykształceniem zawodowym innym niż rolnicze, ale posiadających co najmniej 5-letni staż pracy w rolnictwie.

Wyniki przeprowadzonych badań potwierdziły, że rolnictwo jest sektorem gospodarki, w którym nie tyle posiadanie informacji i wiedzy, jak praktyczne ich zastosowanie jest szczególnie ważne. Aby osiągnąć sukces w prowadzeniu gospodarstwa konieczne jest solidne przygotowanie zawodowe, na którym nie można jednak poprzestać. Prowadzenie działalności rolniczej w warunkach wolnego rynku i nieustannych zmian zachodzących w otoczeniu gospodarstwa wymaga stałego dostępu do aktualnych źródeł informacji. Dowodem tego jest fakt, że 63 respondentów aktualizowało swoją wiedzę poprzez samokształcenie, 60 formalnie uczestnicząc w kursach czy szkoleniach. Zaledwie 4 osoby nie czyniły tego uważając, że posiadana przez nie wiedza jest wystarczająca lub argumentując to brakiem wolnego czasu. Jak wynika $\mathrm{z}$ informacji zestawionych na rys. 3 wśród źródeł wiedzy na temat działalności rolniczej wymieniano m.in.: doradztwo rolnicze (56 odpowiedzi), wymianę informacji z innymi rolnikami (47 odpowiedzi), obserwację innych rolników (34 odpowiedzi), czy wyjazdy studyjne (12 odpowiedzi).

W trakcie badań założono, że realizacja inwestycji, a przede wszystkim wprowadzanie nowych rozwiązań jest ściśle powiązane z posiadanymi przez producentów rolnych kompetencjami. Kompetencje mogą być rozumiane jako specyficzne umiejętności oraz cechy ukierunkowane na osiąganie możliwie

${ }^{5}$ Z Raportu o stanie wsi (2014) wynika, że po 10 latach członkostwa Polski w Unii Europejskiej wyraźnie wzrósł poziom kapitału ludzkiego zarówno wśród rolników, jak i pozostałych mieszkańców wsi. Oceniając kapitał ludzki przez pryzmat poziomu wykształcenia, umiejętności i doświadczenia wiele zmieniło się na korzyść. Przejawia się to w systematycznym zmniejszaniu się odsetka osób z wykształceniem podstawowym, zwiększeniu odsetka rolników korzystających z Internetu oraz deklarujących znajomość języków obcych (Fedyszak-Radziejowska 2014). 
najwyższego poziomu satysfakcji. W związku z tym badani dokonali samooceny określonych kompetencji w skali od 1 do 5 , gdzie 1 oznaczało poziom bardzo niski, natomiast 5 - bardzo wysoki. $Z$ danych zestawionych w tab. 1 wynika, że dokonując autocharakterystyki respondenci najwyżej ocenili samodzielne podejmowanie decyzji, zainteresowanie nowymi rozwiązaniami (innowacjami), zdolność do podejmowania decyzji oraz przedsiębiorczość. W przypadku wymienionych kompetencji średnia arytmetyczna wyniosła odpowiednio: 3,84 ; 3,$76 ; 3,74 ; 3,71$.

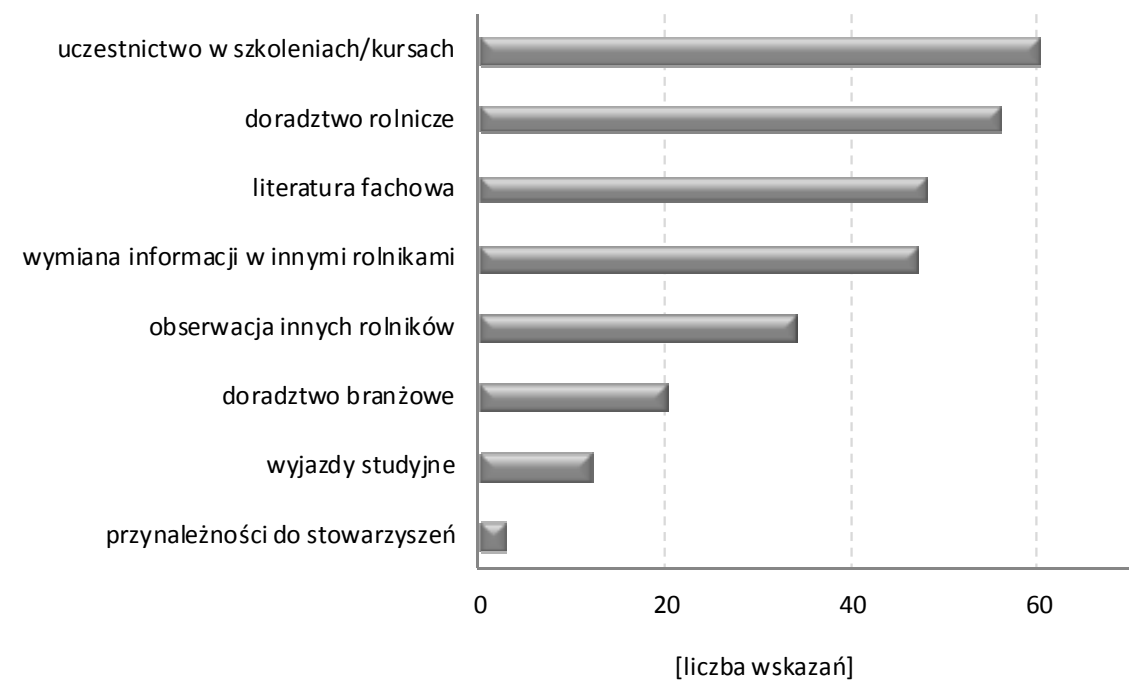

Rys. 3. Źródła wiedzy na temat działalności rolniczej

Źródło: opracowanie na podstawie wyników badań własnych, $\mathrm{n}=74$

Ze względu na fakt występowania nieznacznych różnic w ocenie podanych 19 kompetencji, zdecydowano się na pomiar dyspersji. Najwyższe zróżnicowanie udzielanych odpowiedzi odnotowano w przypadku umiejętności korzystania z Internetu, skłonności do podejmowania ryzyka oraz chęci dokształcania się.

Struktura odpowiedzi udzielonych przez badanych producentów rolnych w kwestii samooceny posiadanych kompetencji nie pozwoliła jednoznacznie ocenić czy faktycznie kompetencje miały wpływ na decyzje o podjęciu inwestycji i unowocześnianiu gospodarstw, czy też nie. Podobnie - odnosząc fakt realizowania lub nierealizowania inwestycji do wieku czy wykształcenia. Okazało się bowiem, że grupa 6 rolników, którzy nie zdecydowali się na inwestycje była zróżnicowana zarówno wiekowo (występowali rolnicy ze wszystkich grup wiekowych), jak i pod względem wykształcenia (połowa posiadała wykształcenie rolnicze różnego stopnia, pozostali -inne). 
Samoocena kompetencji producentów rolnych realizujących inwestycje w latach 2004-2013

\begin{tabular}{|c|c|c|c|c|c|c|c|c|c|c|}
\hline \multirow[t]{2}{*}{ Samoocena kompetencji } & \multicolumn{5}{|c|}{$\begin{array}{c}\text { Ocena w skali } \\
\text { od } 1 \text { do } 5 \text {, gdzie: } \\
1 \text { - poziom bardzo } \\
\text { niski } \\
2 \text { - poziom niski } \\
3 \text { - poziom } \\
\text { przeciętny } \\
4 \text { - poziom wysoki } \\
5 \text { - poziom bardzo } \\
\text { wysoki } \\
\end{array}$} & \multirow[t]{2}{*}{$\begin{array}{l}\tilde{D} \\
\tilde{N} \\
\widetilde{\sim}\end{array}$} & \multirow[t]{2}{*}{ 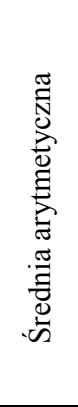 } & \multirow[t]{2}{*}{ 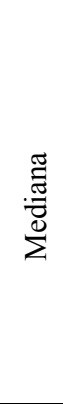 } & \multirow[t]{2}{*}{ 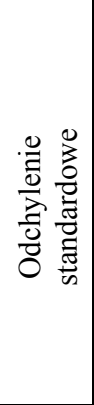 } & \multirow[t]{2}{*}{ 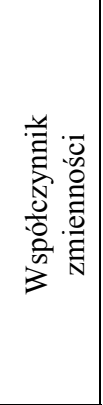 } \\
\hline & 1 & 2 & 3 & 4 & 5 & & & & & \\
\hline 1 & 2 & 3 & 4 & 5 & 6 & 7 & 8 & 9 & 10 & 11 \\
\hline $\begin{array}{l}\begin{array}{l}\text { Zdolność do tworzenia nowych } \\
\text { rozwiązań }\end{array} \\
\end{array}$ & 0 & 2 & 35 & 23 & 8 & 68 & 3,54 & 3,0 & 0,742 & 20,930 \\
\hline Skłonność do wprowadzania zmian & 0 & 3 & 27 & 27 & 11 & 68 & 3,68 & 4,0 & 0,800 & 21,761 \\
\hline Skłonność do podejmowania ryzyka & 2 & 9 & 29 & 18 & 10 & 68 & 3,37 & 3,0 & 0,991 & 29,429 \\
\hline Przedsiębiorczość & 1 & 2 & 24 & 30 & 11 & 68 & 3,71 & 4,0 & 0,830 & 22,387 \\
\hline Zdolność do podejmowania decyzji & 0 & 1 & 28 & 27 & 12 & 68 & 3,74 & 4,0 & 0,765 & 20,487 \\
\hline \begin{tabular}{|l|} 
Zainteresowanie nowymi \\
rozwiązaniami (innowacjami)
\end{tabular} & 0 & 3 & 22 & 31 & 12 & 68 & 3,76 & 4,0 & 0,794 & 21,090 \\
\hline Chęć do nauki & 1 & 5 & 33 & 21 & 8 & 68 & 3,44 & 3,0 & 0,853 & 24,792 \\
\hline Wiedza o prawach rynku & 0 & 8 & 39 & 20 & 1 & 68 & 3,21 & 3,0 & 0,659 & 20,563 \\
\hline $\begin{array}{l}\text { Zdolność rozwiązywania } \\
\text { problemów }\end{array}$ & 0 & 0 & 31 & 32 & 5 & 68 & 3,62 & 4,0 & 0,624 & 17,239 \\
\hline Kreatywność & 1 & 1 & 33 & 24 & 9 & 68 & 3,57 & 3,0 & 0,798 & 22,322 \\
\hline Zorientowanie na wiedzę & 0 & 4 & 27 & 25 & 12 & 68 & 3,66 & 4,0 & 0,840 & 22,927 \\
\hline Umiejętność korzystania z Internetu & 2 & 7 & 31 & 15 & 14 & 69 & 3,44 & 3,0 & 1,013 & 29,440 \\
\hline $\begin{array}{l}\text { Terminowa realizacja zaplanowa- } \\
\text { nych zadań }\end{array}$ & 1 & 3 & 31 & 25 & 8 & 68 & 3,53 & 3,0 & 0,819 & 23,205 \\
\hline Samodzielne podejmowanie decyzji & 0 & 1 & 22 & 32 & 13 & 68 & 3,84 & 4,0 & 0,745 & 19,419 \\
\hline Odporność na stres & 0 & 5 & 29 & 24 & 10 & 68 & 3,57 & 3,5 & 0,834 & 23,346 \\
\hline Przydzielanie zadań innym osobom & 0 & 7 & 36 & 17 & 8 & 68 & 3,38 & 3,0 & 0,829 & 24,513 \\
\hline Koordynowanie pracy innych osób & 0 & 1 & 33 & 24 & 10 & 68 & 3,63 & 3,5 & 0,751 & 20,681 \\
\hline Zdolność szybkiego uczenia się & 0 & 5 & 31 & 26 & 6 & 68 & 3,49 & 3,0 & 0,763 & 21,886 \\
\hline Zorientowanie na rozwój & 2 & 0 & 32 & 28 & 6 & 68 & 3,53 & 3,5 & 0,782 & 22,148 \\
\hline
\end{tabular}

Źródło: opracowanie na podstawie wyników badań własnych, $\mathrm{n}=68$.

Z tego względu zdecydowano o obliczeniu wskaźnika ważności kompetencji w grupie producentów mleka, którzy w latach 2004-2013 zrealizowali inwestycje. Zestawione na rys. 4 informacje pozwoliły stwierdzić, że posiadane 
kompetencje miały wpływ na fakt realizacji inwestycji, że nie wystąpiły duże różnice wartości wag poszczególnych kompetencji. Na podstawie dokonanej hierarchizacji zmiennych ustalono, że kompetencjami, które miały najwyższe wagi były: chęć do nauki i zorientowanie na wiedzę, wyniosły one odpowiednio 0,1535 i 0,1506 .

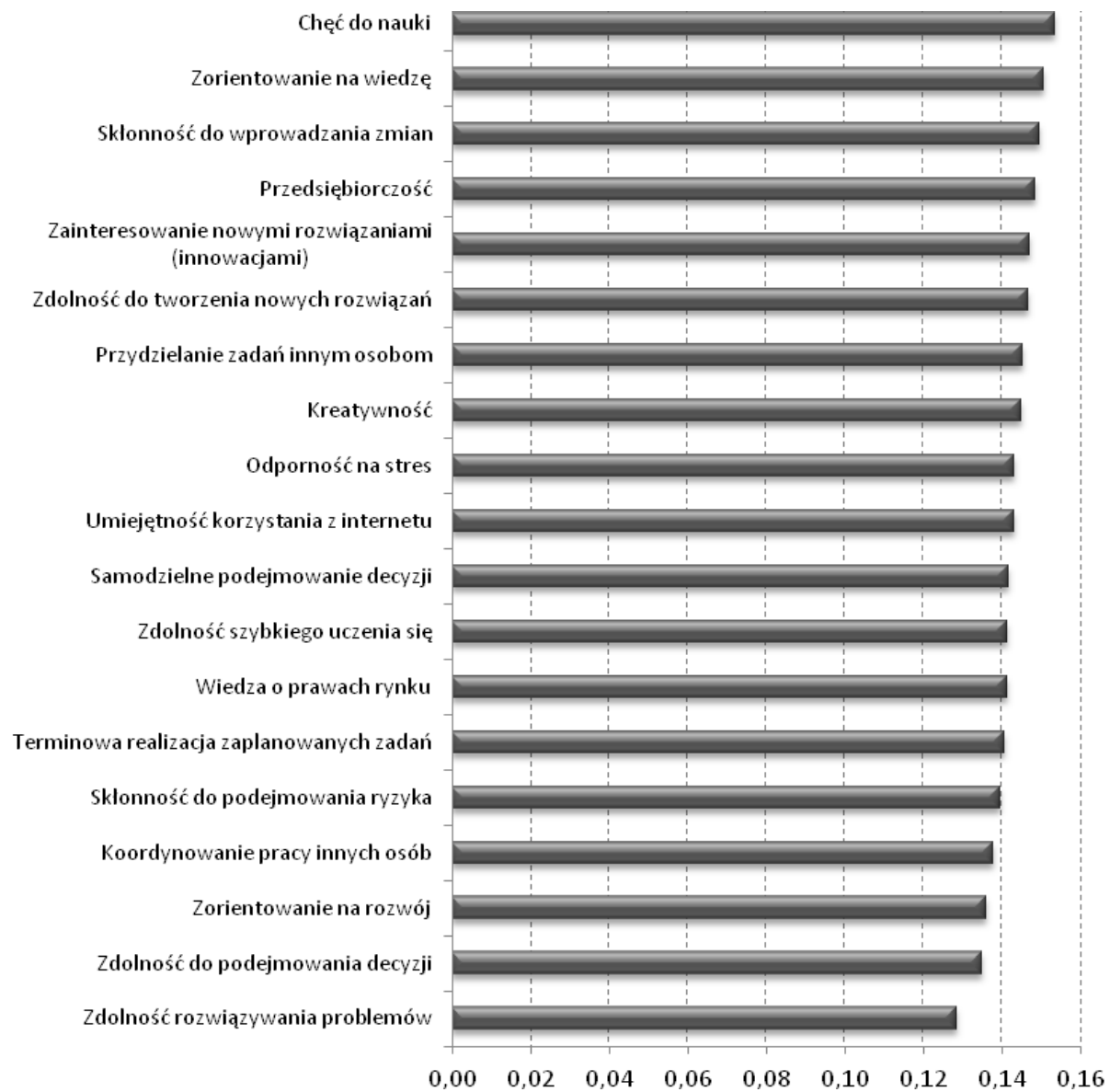

Rys. 4. Wartość wskaźnika ważności poszczególnych kompetencji u producentów rolnych w gospodarstwach inwestujących

Źródło: opracowanie na podstawie wyników badań własnych

$\mathrm{Z}$ kolei najniższe wagi zaobserwowano w przypadku takich kompetencji jak: zdolność rozwiązywania problemów $(0,1282)$, zdolność do podejmowania decyzji $(0,1347)$, zorientowanie na rozwój $(0,1359)$, koordynowanie pracy innych osób $(0,1376)$ oraz skłonność do podejmowania ryzyka $(0,1394)$. 


\section{Wnioski}

Zmiany zachodzące $\mathrm{w}$ otoczeniu gospodarstwa, a przede wszystkim fakt uczestnictwa $\mathrm{w}$ wolnym rynku, zmusza producentów rolnych do ciągłego aktualizowania swojej wiedzy, co potwierdzają przeprowadzone badania. Aż $85 \%$ respondentów czyniło to $\mathrm{w}$ formie regularnego lub nieregularnego samokształcenia, a 81\% - uczestnicząc w kursach, szkoleniach. Ze sposobem aktualizowania posiadanej wiedzy ściśle związane były główne jej źródła, wśród których wymieniano najczęściej uczestnictwo w kursach/szkoleniach, literaturę fachową. Ważne jest jednak, że źródłem inspiracji i wiedzy dla badanych były także kontakty z innymi osobami. Liczna grupa korzystała ze wsparcia doradców rolniczych (48), ale również wymiany informacji z innymi rolnikami (47).

Kapitał ludzki jest ważny w procesie polepszania wyników gospodarowania $\mathrm{w}$ rolnictwie, szczególnie $\mathrm{w}$ aspekcie właściwego zarządzania oraz organizacji i wykorzystania czynników produkcji. Wśród kompetencji charakteryzujących rolników unowocześniających swoje gospodarstwa najwyżej oceniano zainteresowanie nowymi rozwiązaniami, zdolność do podejmowania decyzji oraz przedsiębiorczość. Dostrzeżono również kompetencje, w przypadku których samoocena była dużo niższa, np. wiedza o prawach rynku, czy też skłonność do podejmowania ryzyka. Producenci rolni dokonujący inwestycji zdecydowanie wyżej oceniali posiadane kompetencje niż osoby, które w latach 2004-2013 nie zrealizowały żadnych inwestycji w prowadzonych gospodarstwach. Świadczyły o tym różnice w wartości wskaźnika ważności kompetencji przemawiające na korzyść pierwszej grupy. Daje to podstawę do stwierdzenia, że czynnik ludzki, a przede wszystkim jakość kapitału ludzkiego ma wpływ na unowocześnianie gospodarstw rolnych, choć z pewnością nie jest jedyną cechą kształtującą ten proces.

\section{LITERATURA}

Babuchowska K., Marks-Bielska R., 2012, Unowocześnianie gospodarstw rolnych z województwa warmińsko-mazurskiego w ramach PROW 2007-2013, „Zeszyty Naukowe SGGW, Polityki Europejskie, Finanse i Marketing”, 8(57), s. 36-46.

Babuchowska K., Marks-Bielska R., Lizińska W., 2013, Rola Agencji Nieruchomości Rolnych $w$ ograniczaniu barier $w$ procesie unowocześniania gospodarstw rolnych, [w:] Marks-Bielska R., Kisiel R. (red.), Rola Agencji Nieruchomości Rolnych w unowocześnianiu rolnictwa i obszarów wiejskich, Wydawnictwo UWM, Olsztyn, s. 129145.

Chyłek E., 2005, Proces modernizacji rolnictwa i obszarów wiejskich w Polsce, „Wieś i Rolnictwo", 3(128), s. 9-20.

Dudek M., 2008, Rola czynnika ludzkiego $w$ rolnictwie indywidualnym na przykładzie gospodarstw emerytów i młodych rolników, IERiGŻ, Warszawa. 
Dudek M., Chmieliński P., 2011, Znaczenie kapitału ludzkiego - uwagi teoretyczne, [w:] Sikorska A. (red.), Uwarunkowania rozwoju kapitału ludzkiego w rolnictwie i na obszarach wiejskich, Wydawnictwo IERiGŻ, Warszawa, s. 11-58.

Dudzińska-Głaz J., 2012, Zarzadzanie kompetencjami pracowników jako jeden z elementów strategicznego zarządzania zasobami ludzkimi, [w:] Harasim W. (red.), Zarzadzanie kapitałem intelektualnym $w$ organizacji inteligentnej, Wyższa Szkoła Promocji, Warszawa, s. 82-100.

Fedyszak-Radziejowska B., 2014, Społeczności wiejskie dziesięć lat po akcesji. Postawy, wartości i uwarunkowania społeczno-ekonomiczne, [w:] Nurzyńska I., Poczta W. (red.), Polska wieś 2014. Raport o stanie wsi, Wydawnictwo Naukowe Scholar, Warszawa, s. 153-174.

Glejbowicz E., Chlebicka A., 2012, Wspieranie innowacyjności w ramach WPR: dotychczasowe doświadczenia i nowe propozycje legislacyjne, FAPA, Warszawa.

Gradziuk B., 2008, Kapitał ludzki elitarnych gospodarstw rolniczych, „Wieś i Rolnictwo", 2(139), s. 86-103.

Jain H.K., 2012, Transition to twenty-first century agriculture: change of direction, „Agricultural Research”, 1(1), s. 12-17.

Jarecki W., 2003, Koncepcja kapitatu ludzkiego, [w:] Kopycińska D. (red.), Kapitat ludzki w gospodarce, Wydawnictwo PTE, Szczecin.

Kisiel R., Babuchowska K., 2013, Nakłady inwestycyjne $w$ gospodarstwach rolnych ujęcie regionalne, „Roczniki Ekonomiki Rolnictwa i Rozwoju”, 100(1), s. 1-8.

Kola M., Kujawka M., Kuzel M., 2005, Badanie uwarunkowań i skutków bezpośrednich inwestycji zagranicznych $w$ województwie kujawsko-pomorskim, [w:] Karaszewski W. (red.), Bezpośrednie inwestycje zagraniczne w województwie kujawsko-pomorskim (stan, znaczenie dla gospodarki województwa, stymulanty i destymulanty naply$w u$ ), Wydawnictwo UMK w Toruniu, Wydział Nauk Ekonomicznych i Zarządzania, Toruń, s. 33-45.

Kowalski A., 2009, Czynniki wplywajace na kierunki rozwoju rolnictwa $w$ zmieniajacym się świecie, [w:] Przyszłość sektora rolno-spożywczego i obszarów wiejskich, I Kongres Nauk Rolniczych Nauka - Praktyce, s. 3-13.

Kowalski A., 2010, Wstep, [w:] Kowalski A. (red.), Ekonomiczne i społeczne uwarunkowania rozwoju polskiej gospodarki żywnościowej po wstapieniu Polski do Unii Europejskiej (Synteza), IERiGŻ, Warszawa, s. 7-10.

Kożuch B., Kożuch A., 2008, Kapitat intelektualny i ludzki - istota i znaczenie, „Studia i Prace Wydziału Nauk Ekonomicznych i Zarządzania Uniwersytetu Szczecińskiego", 8, s. 177-182.

Krzyżanowska K., 2000, Skuteczność upowszechniania postępu organizacyjnego $w$ rolnictwie - strategie doradcze, Wydawnictwo SGGW, Warszawa.

Lubbe A., 2011, Transformacja, modernizacja czy po prostu normalizacja? Wybory modelu gospodarki polskiej po 1989 roku, [w:] Morawski W. (red. nauk.), Modernizacja Polski. Struktury - Agencje - Instytucje, Wydawnictwo Akademickie i Profesjonalne, Warszawa, s. 54-89.

Marks-Bielska R., 2006, Kapitat ludzki a kwestia ubóstwa w środowiskach popegeerowskich. Nierówności spoleczne a wzrost gospodarczy. Problemy globalizacji i regionalizacji, cz. 2, Uniwersytet Rzeszowski, Rzeszów.

OECD, 1998, Human capital investment. An international comparison, Centre for Educational Research and Innovation. 
Parysek J.J., 2001, Podstawy gospodarki lokalnej, Wydawnictwo Naukowe Uniwersytetu im. Adama Mickiewicza w Poznaniu, Poznań.

Rosińska M., 2007, Kapitat ludzki podstawa budowania przewagi konkurencyjnej wspótczesnych przedsiębiorstw, [w:] Bogdanienko J., Kuzel M., Sobczak I. (red.), Uwarunkowania budowania konkurencyjności przedsiębiorstw $w$ otoczeniu globalnym, Wydawnictwo Adam Marszałek, Toruń, s. 11-20.

Staniszewski J., 2014, Doradztwo rolnicze jako element instytucjonalnego otoczenia polskiej wsi, Roczniki Ekonomiczne Kujawsko-Pomorskiej Szkoły Wyższej w Bydgoszczy, s. 266-276.

Wilkin J., 2006, Człowiek w ekonomii, czyli o kwestii zasobów ludzkich w kapitat, [w:] Szafraniec K. (red.), Jednostkowe i społeczne zasoby wsi, IRWiR PAN, Warszawa, s. $97-106$.

Woś A., 1987, Rozwój i postęp w rolnictwie polskim, Państwowe Wydawnictwo Rolnicze i Leśne, Warszawa.

\title{
THE ROLE OF THE HUMAN FACTOR IN THE MODERNIZATION OF POLISH AGRICULTURE ON THE EXAMPLE OF MILK PRODUCERS
}

\begin{abstract}
Progress implemented in agricultural production is conditioned by many factors. Among them, very important is agricultural producers attitudes. Therefore, the main aim of study was concentrate on self-assessment of the competence of agricultural producers in the process of modernization theirs farms. Particular attention was focused on the farmers competence and education, sources of theirs knowledge and ways of its updating. The main source of information was the primary data collected through direct interviews conducted with the owners of 74 dairy farms in the warmińsko-mazurskie voivodeship. For the data's analysis used descriptive statistics and the severity rating. Based on the survey, there was no connection between attaining the investment or not and the age and education. Hierarchy of competencies by of severity has shown that the most important in the process of modernization of dairy farms were being eager to learn and orientation to knowledge.
\end{abstract}

Key words: human kapital, innovations, milk production, modernization.

Dr Karolina Babuchowska

Dr hab. Renata Marks-Bielska, prof. UWM

Katedra Polityki Gospodarczej i Regionalnej Wydział Nauk Ekonomicznych

Uniwersytet Warmińsko-Mazurski w Olsztynie 